\title{
New Glycosides from the Japanese Fern Hymenophyllum barbatum
}

\author{
Masao TоYota, ${ }^{*}$ Yasushi Oiso, and Yoshinori Asakawa \\ Faculty of Pharmaceutical Sciences, Tokushima Bunri University, Yamashiro-cho, Tokushima 770-8514, Japan. \\ Received November 16, 2001; accepted December 27, 2001
}

Thirteen glycosides and methyl $(3 R, 5 R)-5$-hydroxy-( $\beta$-D-glucopyranosyloxy)-hexanoate were newly isolated from the Japanese fern Hymenophyllum barbatum, although our previous work revealed the isolation of hemiterpene glycosides, hymenosides A-J, from the same species. The structures of the newly isolated glycosides were elucidated by extensive two-dimensional (2D) NMR and/or chemical evidence. The structures of those aglycones were divided into four types, 2-methyl-but-2-ene-1,4-diol, 2-hydroxymethyl-but-2-ene-1,4-diol, 2-methylene-butane-1,3,4-triol, and 3-hydroxy-5-hexanolide. The sugar moieties, which were acylated by phenylacetic acid derivatives, were also established by chemical and spectroscopic methods. Eight glucosides of the isolated compounds in the present investigation had a bitter or weakly pungent taste. It is clear that a phenylacetyl group attached to glucose or allose as an ester is necessary for the bitter taste.

Key words Hymenophyllum barbatum; hemiterpene glycoside; fern; pteridophytes; bitter taste

We have focused on the bioactive constituents and chemosystematics of bryophytes and pteridophytes, as well as the evolutionary relationship between terrestrial sporeforming green plants and algae using their characteristic chemical indicators. ${ }^{1-9)}$

Two different traditional views of the evolutionary relationships between bryophytes and pteridophytes have been reported. ${ }^{10)}$ If ferns and bryophytes are indeed close to the main line of evolution of other vascular plants, then indicators of such links may be present in some chemical congruence. In our continuing chemosystematic research on cryptogamous plants, including bryophytes and pteridophytes, we reported that an acyclic bisbibenzyl characteristic of liverworts was present in the fern Hymenophyllum barbatum. ${ }^{4)}$ The compound was considered to be a chemical fossil that could link bryophytes and ferns.

In the course of the investigation of bioactive substances of New Zealand pteridophytes and bryophytes, we found that
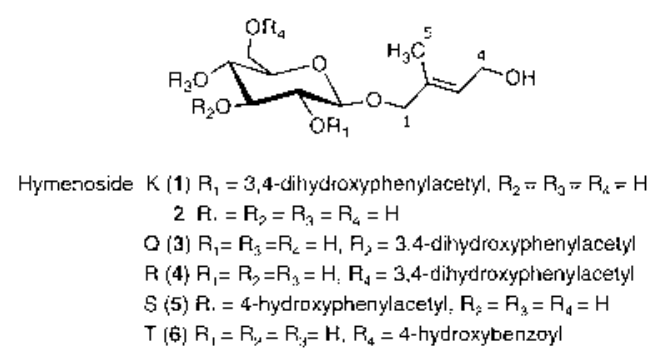

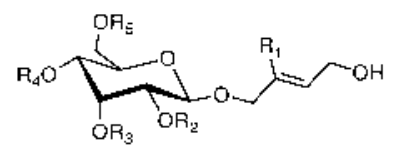

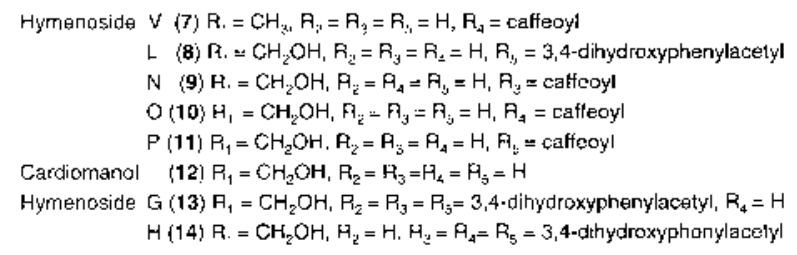

* To whom correspondence should be addressed. e-mail: toyota@ph.bunri-u.ac.jp some ferns contain a potent hot-tasting substance. This resulted in the isolation of (-)-polygodial from the New Zealand fern Blechnum fluviatile. ${ }^{11)}$ Recently, we reported the isolation of hemiterpene glycosides, hymenoside A- J, which had a bitter or weakly hot taste, from the Japanese fern Hymenophyllum barbatum. ${ }^{1,2)}$

After the extraction of $H$. barbatum with methanol, the crude extract was partitioned between water and ethyl acetate, and then extracted with $n$-butanol. The $n$-butanol-soluble fraction was subjected to repeated chromatography on DIAION HP-20, silica gel, and Sephadex LH-20 columns, followed by preparative HPLC to yield thirteen glycosides, hymenosides $\mathrm{K}-\mathrm{W}(\mathbf{1}, \mathbf{3}-\mathbf{1 1}, \mathbf{1 5}-\mathbf{1 7})$, together with methyl $(3 R, 5 R)$-hydroxy-( $\beta$-D-glucopyranosyloxy)-hexanoate (19). ${ }^{2)}$

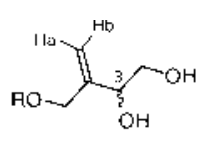
Hymenoside $M(15) \mathrm{R}=$ allopyranose
W(16) $\mathrm{F}$ - glueopyranoso

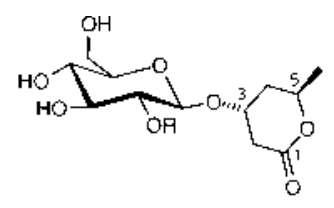

Hymenoside U (17) $F=3$, 4-dihydroxyphendacety'

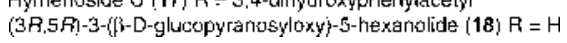


Hymenoside $\mathrm{K}(\mathbf{1}),[\alpha]_{\mathrm{D}}-18.5^{\circ}$, is a glucoside, as evidenced by the signals attributed to a $\beta$-glucopyranose unit in the ${ }^{1} \mathrm{H}$ - and ${ }^{13} \mathrm{C}$-NMR spectra (Tables 1,2 ). Actually, the ${ }^{1} \mathrm{H}$ NMR of 1 showed an anomeric proton at $\delta 4.88$ coupled with $\mathrm{H}-2^{\prime}$ at $\delta 5.65$ (brt, $J=8 \mathrm{~Hz}$ ). The coupling constant $J_{\mathrm{H} 1^{\prime}, 2^{\prime}}$ value $(\mathrm{d}, J=8 \mathrm{~Hz})$ of $\mathrm{H}-1^{\prime}$ amply demonstrated the $\beta$ configuration. The positive-FAB-MS spectrum gave a quasimolecular ion peak at $\mathrm{m} / z 437$ and its high resolution (HR)FAB-MS resulted in the molecular formula $\mathrm{C}_{19} \mathrm{H}_{26} \mathrm{O}_{10} \mathrm{Na}$. The ${ }^{1} \mathrm{H}-\mathrm{NMR}$ spectrum of $\mathbf{1}$ showed two oxygenated methylenes at $\delta 4.11,4.31$ (each $1 \mathrm{H}$, brd, $J=12 \mathrm{~Hz}, \mathrm{H}-1$ ) and 4.43 $(2 \mathrm{H}$, brd, $J=6 \mathrm{~Hz}, \mathrm{H}-4)$, and a vinyl methyl group and an olefinic proton at $\delta 1.65(3 \mathrm{H}, \mathrm{H}-5)$ and $6.04(1 \mathrm{H}, \mathrm{H}-3)$. The presence of the aromatic ring was apparent from the absorption band at $283 \mathrm{~nm}(\log \varepsilon, 3.47)$ in the UV spectrum of 1 . The ${ }^{1} \mathrm{H}-\mathrm{NMR}$ spectrum further provided evidence for the presence of a 3,4-dihydroxyphenylacetyl group, namely, three protons at $\delta 6.93\left(\mathrm{dd}, J=8,2 \mathrm{~Hz}, \mathrm{H}-6^{\prime \prime}\right), 7.17$ (d, $\left.J=8 \mathrm{~Hz}, \mathrm{H}-5^{\prime \prime}\right)$ and $7.38\left(\mathrm{~d}, J=2 \mathrm{~Hz}, \mathrm{H}-2^{\prime \prime}\right)$ were assigned to the 1,3,4-tri-substituted aromatic ring, and $\mathrm{AB}$ type system protons at $\delta 3.79$ and 3.84 (each, d, $J=15 \mathrm{~Hz}, \mathrm{H}-\alpha$ ) were assigned to an isolated methylene proton of the 3,4-hydroxyacetophenyl group. This is based on the methylene proton $\left(\mathrm{H}_{2}-\alpha\right)$ being coupled with a carbonyl carbon signal at $\delta$ 171.6 through ${ }^{1} \mathrm{H}-{ }^{13} \mathrm{C}$ long-range; further coupling between the carbonyl carbon and $\mathrm{H}-2^{\prime}$ proton signal at $\delta 5.65$ were observed in its heteronuclear multiple bond correlation (HMBC) spectra (summarized in Fig. 1). It was apparent that the 3,4-dihydroxyphenyl group was esterified on C-2' of the glucopyranose. The acidic hydrolysis of $\mathbf{1}$ provided further evidence for the presence of the 3,4-dihydroxyphenyl group. The basic hydrolysis of $\mathbf{1}$ gave a glucoside, of which the ${ }^{1} \mathrm{H}$ and ${ }^{13} \mathrm{C}$-NMR spectral data were identical to those of $\mathbf{2}$ isolated from Ornithogalum montanum (Liliaceae). ${ }^{12)}$ Further hydrolysis of 2 with $5 \%$ sulfuric acid afforded glucose, which was identified as (+)-glucose by GC-MS and HPLC equipped with a chiral detector. Accordingly, the structure of 1 was determined to be 2 -(3,4-dihydroxyphenylacetyl)- $\beta$-Dglucopyranosyl $(E)$-2-methyl-but-2-en-4-ol.

The structures of hymenosides Q (3) and R (4) were deduced by comparing the spectral data with those of compound 1. While the HR-FAB-MS spectra gave the same molecular formula as that of $\mathbf{1}$, acylation shifted proton signals at $\delta 5.91\left(\mathrm{t}, J=10 \mathrm{~Hz}, \mathrm{H}-3^{\prime}\right)$ of $\mathbf{3}$ and $\delta 4.75(\mathrm{dd}, J=12,7 \mathrm{~Hz}$, H- $\left.6^{\prime}\right)$ and 5.00 (dd, $\left.J=12,2 \mathrm{~Hz}, \mathrm{H}-6^{\prime}\right)$ of 4 were observed in the ${ }^{1} \mathrm{H}-\mathrm{NMR}$ spectra (Table 1). Assignment of the proton signals was performed by ${ }^{1} \mathrm{H}-{ }^{1} \mathrm{H}$ correlation spectroscopy (COSY) spectra of $\mathbf{3}$ and $\mathbf{4}$, confirming the presence of a 3,4dihydroxyphenylacetyl group at C-3' of 3 and C-6' of 4 . The structures of hymenosides $\mathrm{Q}$ and $\mathrm{R}$ were established as $\mathbf{3}$ and 4 , respectively.

The structures of hymenosides $\mathrm{S}(\mathbf{5})$ and $\mathrm{T}(\mathbf{6})$ were again established by comparing the spectral data with those of $\mathbf{1}$. The ${ }^{1} \mathrm{H}$ - and ${ }^{13} \mathrm{C}$-NMR spectra (Tables 1,2$)$ of 5 were similar to those of 1, except for the absence of the 3,4-dihydroxyphenylacetyl group, and for the appearance of two-proton signals at $\delta 7.39\left(2 \mathrm{H}, \mathrm{d}, J=8.5 \mathrm{~Hz}, \mathrm{H}-2^{\prime \prime}, 6^{\prime \prime}\right)$ and $7.15(2 \mathrm{H}, \mathrm{d}$, $\left.J=8.5 \mathrm{~Hz}, \mathrm{H}-3^{\prime \prime}, 5^{\prime \prime}\right)$ in the ${ }^{1} \mathrm{H}-\mathrm{NMR}$ of 5. Positive FAB-MS of 5 afforded a quasimolecular ion peak at $\mathrm{m} / \mathrm{z} 421.1503$ $\left(\mathrm{C}_{19} \mathrm{H}_{26} \mathrm{O}_{9} \mathrm{Na}\right), 16$ mass units less than that of $\mathbf{1}$, confirming the presence of a 4-hydroxyphenylacetyl group. A correla-

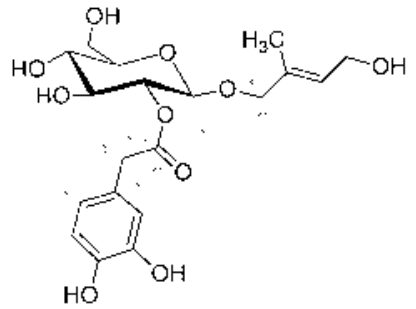

$\mathrm{H} 10^{150} \mathrm{C}$

Fig. 1. Structure of Hymenoside K (1) and Its Long-Range Correlations in the HMBC Spectrum

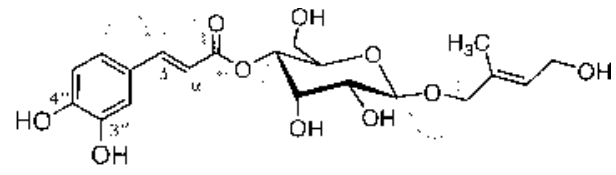

${ }^{1} \mathrm{H}$ to ${ }^{19} \mathrm{C}$

Fig. 2. Structure of Hymenoside V (7) and Its Long-Range Correlations in the HMBC Spectrum

tion between $\mathrm{H}-2^{\prime}$ and an ester carbonyl at $\delta 171.5$ in the HMBC spectrum provided further evidence for the structure of 5. Thus, the structure of hymenoside $\mathrm{S}$ was established as 5. A positive HR-FAB-MS spectrum of $\mathbf{6}$ gave a quasimolecular ion peak at $m / z 407.1333\left(\mathrm{C}_{18} \mathrm{H}_{24} \mathrm{O}_{9} \mathrm{Na}\right)$, which was 14 mass units less than that of 5. Although the ${ }^{1} \mathrm{H}-\mathrm{NMR}$ of 6 gave an $\mathrm{A}_{2} \mathrm{~B}_{2}$ type signal at $\delta 7.12\left(2 \mathrm{H}, \mathrm{d}, J=8.5 \mathrm{~Hz}, \mathrm{H}-2^{\prime \prime}\right.$, $\left.6^{\prime \prime}\right)$ and $8.23\left(2 \mathrm{H}, \mathrm{d}, J=8.5 \mathrm{~Hz}, \mathrm{H}-3^{\prime \prime}, 5^{\prime \prime}\right)$, the signal of the $\mathrm{H}_{2}-$ $\alpha$ proton was not observed in its spectrum. This indicated the presence of a 4-hydroxybenzoyl group in $\mathbf{6}$. The benzoyl group at C-6' was clearly demonstrated from its HMBC spectrum, in which the ${ }^{1} \mathrm{H}-{ }^{13} \mathrm{C}$ long range coupling between the ester carbonyl at $\delta 166.4$ and H-6" at $\delta 5.02$ and 5.18 was observed. Thus, the structure of hymenoside $\mathrm{T}$ was established as 6.

The positive HR-FAB-MS of hymenoside V (7) showed a quasimolecular ion peak at $m / z$ 449.1406, $\left(\mathrm{C}_{20} \mathrm{H}_{26} \mathrm{O}_{10} \mathrm{Na}\right)$. The presence of an allopyranose and $(E)$-2-methyl-but-2-ene1,4-diol was apparent from the ${ }^{13} \mathrm{C}$ - and ${ }^{1} \mathrm{H}-\mathrm{NMR}$ data $(\mathrm{Ta}-$ bles 1,2 ) of 7 . The ${ }^{1} \mathrm{H}-\mathrm{NMR}$ spectrum exhibited signals of a caffeoyl group: i) at $\delta 6.53$ and 7.73 (each $1 \mathrm{H}, \mathrm{d}, J=16 \mathrm{~Hz}$, $\mathrm{H}-\alpha, \beta)$; ii) at $\delta 7.06\left(1 \mathrm{H}, \mathrm{dd}, J=8,2 \mathrm{~Hz}, \mathrm{H}-6^{\prime \prime}\right), 7.21(1 \mathrm{H}, \mathrm{d}$, $\left.J=8 \mathrm{~Hz}, \mathrm{H}-5^{\prime \prime}\right)$, and $7.52\left(1 \mathrm{H}, \mathrm{d}, J=2 \mathrm{~Hz}, \mathrm{H}-2^{\prime \prime}\right)$. The acidic hydrolysis of 7 gave allose, identified by gas chromatography (GC)-MS. Analysis of the ${ }^{1} \mathrm{H}$-detected heteronuclear multiple quantum coherence (HMQC) and HMBC spectra (summarized in Fig. 2) supports the structural assignment. In particular, the long range ${ }^{1} \mathrm{H}-{ }^{13} \mathrm{C}$ correlation of $\mathrm{H}-\alpha$ and $\beta$ with a carbonyl carbon at $\delta 167.0$, and further correlation between the carbonyl carbon and $\mathrm{H}-4^{\prime}$ at $\delta 5.61(\mathrm{dd}, J=10,3 \mathrm{~Hz}$ ), supported the position of the caffeoyl group at C-4' of allopyranose. These chemical and spectral data led to the structure 7 for hymenoside $\mathrm{V}$.

Compounds 8-11 were glycosides, as evident by the signals attributed in the ${ }^{1} \mathrm{H}$ - and ${ }^{13} \mathrm{C}-\mathrm{NMR}$ spectra (Tables 1,2 ) to an allose unit, which linked to an aglycone as the $\beta$-configuration $\left(J_{\mathrm{H}^{\prime}, 2^{\prime}}=8 \mathrm{~Hz}\right)$. 


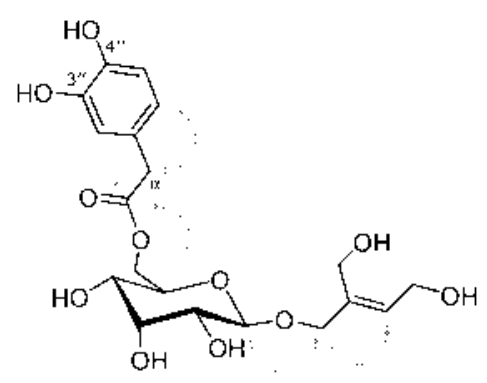

$1 \mathrm{H}$ to ${ }^{15} \mathrm{C}$

Fig. 3. Structure of Hymenoside L (8) and Its Long-Range Correlations in the HMBC Spectrum

The acid hydrolysis of $\mathbf{8}$ - $\mathbf{1 1}$ gave an allose identified by GC-MS analysis and comparison with its authentic sample, confirming the presence of allose in the molecule of $8-\mathbf{1 1}$. The ${ }^{1} \mathrm{H}-\mathrm{NMR}$ spectrum of $\mathbf{9}$ was similar to that of cardiomanol (12), ${ }^{2,13)}$ except for the appearance of five signals due to a caffeoyl group at $\delta 6.70(\mathrm{~d}, J=16 \mathrm{~Hz}, \mathrm{H}-\alpha), 7.08$ (dd, $J=8,2 \mathrm{~Hz}, \mathrm{H}-6^{\prime \prime}$ ), 7.18 (d, $\left.J=8 \mathrm{~Hz}, \mathrm{H}-5^{\prime \prime}\right), 7.51$ (d, $\left.J=2 \mathrm{~Hz}, \mathrm{H}-2^{\prime \prime}\right)$, and $8.01(\mathrm{~d}, J=16 \mathrm{~Hz}, \mathrm{H}-\beta)$ in the former. The basic hydrolysis of 9 afforded an allopyranoside, the ${ }^{1} \mathrm{H}$ NMR spectrum of which was identical to that of cardiomanol (12) obtained from the fern Cardiomanes reniforme, ${ }^{13)}$ and also isolated from the present species. Acid hydrolysis of 9 gave a caffeic acid, confirming the presence of the caffeoyl group, and its position was apparent from the downfield shift of the H-3' proton $(\delta 6.49)$ in the ${ }^{1} \mathrm{H}-\mathrm{NMR}$ spectrum of 9. The ${ }^{1} \mathrm{H}-\mathrm{NMR}$ spectrum (Table 1) of $\mathbf{8}$ was similar to that of hymenosides $\mathrm{G}(\mathbf{1 3})$ and $\mathrm{H}(\mathbf{1 4}),{ }^{2)}$ except for proton signals due to only one acyl group observed in the ${ }^{1} \mathrm{H}-\mathrm{NMR}$ spectrum of $\mathbf{8}$. The acid hydrolysis of $\mathbf{8}$ gave 3,4-dihydroxyphenylacetic acid, identified by GC-MS analysis of its methylated derivative. The HMQC and HMBC spectra supported the structural elucidation of 8-11; particularly important correlations of $\mathbf{8}$ are summarized in Fig. 3. The ${ }^{1} \mathrm{H}-\mathrm{NMR}$ spectra of $\mathbf{1 0}$ and $\mathbf{1 1}$ resembled those of $\mathbf{9}$. An important difference between the ${ }^{1} \mathrm{H}-\mathrm{NMR}$ spectra of 9, 10, 11, and cardiomanol (12) was the chemical shift of a downfield shifted proton of the allopyranose, namely, H-3' of 9 shifted downfield at $\delta 6.49(\mathrm{t}, J=3 \mathrm{~Hz}), \mathrm{H}-4^{\prime}$ of 10 at $\delta 5.61(\mathrm{dd}, J=10$, $3 \mathrm{~Hz}$ ), and $\mathrm{H}_{2}-6^{\prime}$ of 11 at $\delta 4.87(\mathrm{dd}, J=12,6 \mathrm{~Hz})$ and 5.07 (dd, $J=12,2 \mathrm{~Hz}$ ). This indicated the position of the caffeoyl group at C-3' in 9, C-4' in 10, and C-6' in 11, respectively. Accordingly, the structures of hymenosides $\mathrm{L}, \mathrm{N}, \mathrm{O}$ and $\mathrm{P}$ were established to be $\mathbf{8}-\mathbf{1 1}$.

The ${ }^{1} \mathrm{H}-\mathrm{NMR}$ spectrum (Table 1) of hymenoside $\mathrm{M}$ (15) (HR-chemical ionization (CI)-MS, $m / z$ 281.1217, $\mathrm{C}_{11} \mathrm{H}_{21} \mathrm{O}_{8}$ ) gave signals attributed to an allose unit and an exomethylene proton at $\delta 5.26$ and 5.27 (each $1 \mathrm{H}, \mathrm{bs}$ ), and 1,2-glycol unit at $\delta 3.56(1 \mathrm{H}, J=12,7 \mathrm{~Hz}, \mathrm{H}-4), 3.64-3.69$ (H-4' overlapped with $\mathrm{H}-5^{\prime}$ of allose) and $4.27(1 \mathrm{H}$, br t, $J=7 \mathrm{~Hz}, \mathrm{H}-3)$. The HMBC spectrum showed a correlation between the exomethylene proton and a carbon $[\delta 74.4(\mathrm{C}-3)]$ bearing to the secondary hydroxyl group of the 1,2-glycol unit. Further correlation between the exomethylene proton and an oxygenated carbon at $\delta 71.4(\mathrm{C}-1)$, which further correlated to an anomeric proton at $\delta 4.65(\mathrm{~d}, J=8 \mathrm{~Hz})$, was observed in the
HMBC spectrum of $\mathbf{1 5}$. Thus, this indicated the presence of a 2-methylene-butane-1,3,4-triol as an aglycone of $\mathbf{1 5}$. The ${ }^{1} \mathrm{H}-{ }^{1} \mathrm{H}$ spin coupling between $\mathrm{H}-1^{\prime}$ and $2^{\prime}$ showed $8 \mathrm{~Hz}$ in its ${ }^{1} \mathrm{H}-\mathrm{NMR}$, as described earlier, confirming that the structure of 15 was assigned to the $1-O$ - $\beta$-allose of 2 -methylene-butane-1,3,4-triol. An attempt to establish the absolute configuration of the secondary hydroxyl group at C-3 by X-ray crystallographic analysis of its $p$-bromobenzoate is in progress.

The structure of hymenoside W (16) was established by comparing its spectral data with those of hymenoside M (15). Particularly, the ${ }^{13} \mathrm{C}-\mathrm{NMR}$ spectrum (Table 2) of $\mathbf{1 6}$ was similar to that of $\mathbf{1 5}$, although the chemical shift of the signals due to a sugar moiety was different. The coupling pattern of the sugar moiety of $\mathbf{1 6}$ suggested the presence of a glucose. Actually, acidic hydrolysis of $\mathbf{1 6}$ afforded a glucose, whose alditol acetate was identified with a hexaacetate of glucitol by GC-MS analysis. Further analysis of HPLC with a chiral detector gave additional evidence of $(+)$-glucose. Accordingly, the structure of hymenoside $\mathrm{W}$ was $\mathbf{1 6}$.

Compound 17, named hymenoside $U(\mathrm{~m} / \mathrm{z}$ 465.1387, $\mathrm{C}_{20} \mathrm{H}_{26} \mathrm{O}_{11} \mathrm{Na}$ ), was obtained as a viscous colorless oil. The UV spectrum of $\mathbf{1 7}$ showed an absorption band of an aromatic ring at $284 \mathrm{~nm}(\log \varepsilon, 3.51)$. Since compound 17 was presumed to be a glycoside by the signals in the ${ }^{1} \mathrm{H}-\mathrm{NMR}$ data, the enzymatic hydrolysis was performed. This confirmed that the aglycone of $\mathbf{1 7}$ was $(3 R, 5 R)$-3-hydroxy-hexanolide. The coinjection analysis of $(3 R, 5 R)-3$-hydroxy-hexanolide by liquid chromatography (LC)-MS using a chiral column showed a retention time identical to that of the authentic sample. ${ }^{2)}$ The authentic $(3 R, 5 R)$-3-hydroxy-hexanolide has been prepared from the enzymatic hydrolysis of $(3 R, 5 R)-3-$ ( $\beta$-D-glucopyranosyloxy)-5-hexanolide (18), which was isolated from the same species, and its absolute structure was established by X-ray crystallographic analysis of its $p$-bromobenzoate derivative. ${ }^{2)}$ The ${ }^{1} \mathrm{H}$ - and ${ }^{13} \mathrm{C}-\mathrm{NMR}$ (Tables 1,2 ) of $\mathbf{1 7}$ were similar to those of 18, except for the presence of signals due to an acyl group of 17 . The signals at $\delta 3.74(2 \mathrm{H}$, s, H- $\alpha), 6.93\left(1 \mathrm{H}, \mathrm{dd}, J=8,2 \mathrm{~Hz}, \mathrm{H}-6^{\prime \prime}\right), 7.17(1 \mathrm{H}, \mathrm{d}$, $\left.J=8 \mathrm{~Hz}, \mathrm{H}-5^{\prime \prime}\right)$ and $7.38\left(1 \mathrm{H}, \mathrm{d}, J=2 \mathrm{~Hz}, \mathrm{H}-2^{\prime \prime}\right)$ were ascribed to a 3,4-dihydroxyphenylacetyl group in the ${ }^{1} \mathrm{H}-\mathrm{NMR}$ spectrum of 17. The correlation of a carbonyl carbon at $\delta 171.0$ between $\mathrm{H}-2^{\prime}$ at $\delta 5.52(\mathrm{t}, J=8 \mathrm{~Hz})$, and the $\alpha$-proton at $\delta$ 3.74 of the acyl group, was observed in the HMBC spectrum of 17. The above evidence indicated that hymenoside $U$ (17) differed from (3R,5R)-3-( $\beta$-D-glucopyranosyloxy)-5-hexanolide (18) by the replacement of a hydroxyl group at C-2' by a 3,4-dihydroxyphenylacetoxyl group.

Compound 19 related to $\mathbf{1 7}$ and $\mathbf{1 8}$, was attributed to an artifact of 18. Actually, compound 18, which was isolated from the $n$-butanol-soluble fraction of this species, was easily converted to 19 in methanol with an anion exchange resin, Amberlite $120-\mathrm{B}$, the ${ }^{1} \mathrm{H}-\mathrm{NMR}$ spectrum of which was identical with that of methyl $(3 R, 5 R)$-hydroxy- $(\beta$-D-glucopyranosyloxy)-hexanoate. The absolute configuration of $3 R$ and $5 R$ was apparent from the previous measurement of X-ray crystallographic analysis of $18 .^{2)}$ It was reported that $(3 S, 5 S)-5$ hexanolide changed to methyl $(3 S, 5 S)$-hydroxy-hexanoate in methanol. $^{14,15)}$ Compound 19 might be produced from 18 during the extraction with methanol.

Hymenosides G (13), H (14), K (1), Q (3), R (4), S (5), L (8), T (6), U (17) and (3R,5R)-3-( $\beta$-D-glucopyranosyloxy)-5- 
Table 1. ${ }^{1} \mathrm{H}-\mathrm{NMR}$ Data of Hymenosides K (1), Q (3), R (4) and S (5) in Pyridine- $d_{5}$

\begin{tabular}{|c|c|c|c|c|}
\hline No. & $\mathbf{1}^{a)}$ & $3^{b)}$ & $4^{b)}$ & $5^{b)}$ \\
\hline 1 & $\begin{array}{l}4.11,4.31 \\
(\text { each } 1 \mathrm{H}, \text { br d, } J=12 \mathrm{~Hz})\end{array}$ & $\begin{array}{l}4.23,4.47 \\
(\text { each } 1 \mathrm{H}, \text { br d, } J=12 \mathrm{~Hz})\end{array}$ & $\begin{array}{l}4.29,4.50 \\
(\text { each } 1 \mathrm{H}, \text { br d, } J=12 \mathrm{~Hz})\end{array}$ & $\begin{array}{l}4.17,4.39 \\
(\text { each } 1 \mathrm{H}, \text { br d, } J=12 \mathrm{~Hz})\end{array}$ \\
\hline 3 & $6.04(1 \mathrm{H}, \mathrm{brdt}, J=6,1 \mathrm{~Hz})$ & $6.12(1 \mathrm{H}$, br t,$J=5 \mathrm{~Hz})$ & $6.17(1 \mathrm{H}$, br t,$J=6 \mathrm{~Hz})$ & $6.08(1 \mathrm{H}$, br t,$J=6 \mathrm{~Hz})$ \\
\hline 4 & $4.43(2 \mathrm{H}$, br d, $J=6 \mathrm{~Hz})$ & $4.48(2 \mathrm{H}$, br d, $J=5 \mathrm{~Hz})$ & $4.46(2 \mathrm{H}$, br d,$J=6 \mathrm{~Hz})$ & $4.50(2 \mathrm{H}, \mathrm{d}, J=6 \mathrm{~Hz})$ \\
\hline 5 & $1.65(3 \mathrm{H}, \mathrm{s})$ & $1.77(3 \mathrm{H}, \mathrm{s})$ & $1.78(3 \mathrm{H}, \mathrm{s})$ & $1.74(3 \mathrm{H}, \mathrm{s})$ \\
\hline $1^{\prime}$ & $4.88(1 \mathrm{H}, \mathrm{d}, J=8 \mathrm{~Hz})$ & $4.88(1 \mathrm{H}, \mathrm{d}, J=8 \mathrm{~Hz})$ & $4.82(1 \mathrm{H}, \mathrm{d}, J=8 \mathrm{~Hz})$ & $4.95(1 \mathrm{H}, \mathrm{d}, J=8 \mathrm{~Hz})$ \\
\hline $2^{\prime}$ & $5.65(1 \mathrm{H}, \mathrm{brt}, J=8 \mathrm{~Hz})$ & $4.08(1 \mathrm{H}, \mathrm{dd}, J=10,8 \mathrm{~Hz})$ & $4.05^{c)}(1 \mathrm{H}, \mathrm{t}, J=8 \mathrm{~Hz})$ & $5.69(1 \mathrm{H}, \mathrm{t}, J=8 \mathrm{~Hz})$ \\
\hline $3^{\prime}$ & $4.25(1 \mathrm{H}, \mathrm{t}, J=8 \mathrm{~Hz})$ & $5.91(1 \mathrm{H}, \mathrm{t}, J=10 \mathrm{~Hz})$ & $4.18(1 \mathrm{H}, \mathrm{t}, J=8 \mathrm{~Hz})$ & $4.30^{c)}(1 \mathrm{H}, \mathrm{t}, J=8 \mathrm{~Hz})$ \\
\hline $4^{\prime}$ & $4.22(1 \mathrm{H}, \mathrm{t}, J=8 \mathrm{~Hz})$ & $4.35(1 \mathrm{H}, \mathrm{t}, J=10 \mathrm{~Hz})$ & $4.05^{c)}(1 \mathrm{H}, \mathrm{t}, J=8 \mathrm{~Hz})$ & $4.30^{c)}(1 \mathrm{H}, \mathrm{t}, J=8 \mathrm{~Hz})$ \\
\hline $5^{\prime}$ & $3.88(1 \mathrm{H}, \mathrm{ddd}, J=8,5,2 \mathrm{~Hz})$ & $3.91(1 \mathrm{H}, \mathrm{m})$ & $3.98(1 \mathrm{H}, \mathrm{m})$ & $3.95(1 \mathrm{H}, \mathrm{m})$ \\
\hline $6^{\prime}$ & $\begin{array}{l}4.32(1 \mathrm{H}, \mathrm{dd}, J=12,5 \mathrm{~Hz}) \\
4.50(1 \mathrm{H}, \mathrm{dd}, J=12,2 \mathrm{~Hz})\end{array}$ & $\begin{array}{l}4.38(1 \mathrm{H}, \mathrm{dd}, J=12,5 \mathrm{~Hz}) \\
4.49(1 \mathrm{H}, \mathrm{dd}, J=12,1 \mathrm{~Hz})\end{array}$ & $\begin{array}{l}4.75(1 \mathrm{H}, \mathrm{dd}, J=12,7 \mathrm{~Hz}) \\
5.00(1 \mathrm{H}, \mathrm{dd}, J=12,2 \mathrm{~Hz})\end{array}$ & $\begin{array}{l}4.38(1 \mathrm{H}, \mathrm{dd}, J=12,5 \mathrm{~Hz}) \\
4.56(1 \mathrm{H}, \mathrm{dd}, J=12,2 \mathrm{~Hz})\end{array}$ \\
\hline $2^{\prime \prime}$ & $7.38(1 \mathrm{H}, \mathrm{d}, J=2 \mathrm{~Hz})$ & $7.37(1 \mathrm{H}, \mathrm{d}, J=2 \mathrm{~Hz})$ & $7.36(1 \mathrm{H}, \mathrm{d}, J=2 \mathrm{~Hz})$ & $7.39(2 \mathrm{H}, \mathrm{d}, J=8.5 \mathrm{~Hz}), \mathrm{H}-2^{\prime \prime}, 6^{\prime \prime}$ \\
\hline $3^{\prime \prime}$ & & & & $7.15(2 \mathrm{H}, \mathrm{d}, J=8.5 \mathrm{~Hz}), \mathrm{H}-3^{\prime \prime}, 5^{\prime \prime}$ \\
\hline $5^{\prime \prime}$ & $7.17(1 \mathrm{H}, \mathrm{d}, J=8 \mathrm{~Hz})$ & $7.12(1 \mathrm{H}, \mathrm{d}, J=8 \mathrm{~Hz})$ & $7.18(1 \mathrm{H}, \mathrm{d}, J=8 \mathrm{~Hz})$ & \\
\hline $6^{\prime \prime}$ & $6.93(1 \mathrm{H}, \mathrm{dd}, J=8,2 \mathrm{~Hz})$ & $6.91(1 \mathrm{H}, \mathrm{dd}, J=8,2 \mathrm{~Hz})$ & $6.91(1 \mathrm{H}, \mathrm{dd}, J=8,2 \mathrm{~Hz})$ & \\
\hline$\alpha$ & $\begin{array}{l}3.79,3.84 \\
(\text { each } 1 \mathrm{H}, \mathrm{d}, J=15 \mathrm{~Hz})\end{array}$ & $3.79(2 \mathrm{H}, \mathrm{s})$ & $3.72(2 \mathrm{H}, \mathrm{d}, J=3 \mathrm{~Hz})$ & $\begin{array}{l}3.86,3.92 \\
(\text { each, } 1 \mathrm{H}, \mathrm{d}, J=14 \mathrm{~Hz})\end{array}$ \\
\hline
\end{tabular}

Measured at a) $600 \mathrm{MHz}$ and $b$ ) $400 \mathrm{MHz}$. c) Overlapped signals.

Table 1. (Continued) ${ }^{1} \mathrm{H}-\mathrm{NMR}$ Data of Hymenosides, T (6), V (7), L (8) and N (9) in Pyridine- $d_{5}$

\begin{tabular}{|c|c|c|c|c|}
\hline No. & $6^{b)}$ & $7^{a)}$ & $\mathbf{8}^{a)}$ & $9^{a)}$ \\
\hline 1 & $\begin{array}{l}4.31,4.50 \\
\text { (each } 1 \mathrm{H}, \mathrm{d}, J=11 \mathrm{~Hz} \text { ) }\end{array}$ & $\begin{array}{l}4.17,4.47 \\
\text { (each } 1 \mathrm{H}, \text { br d, } J=12 \mathrm{~Hz} \text { ) }\end{array}$ & $\begin{array}{l}4.55-4.61,{ }^{c)} 4.88 \\
(\text { each } 1 \mathrm{H}, \mathrm{d}, J=12 \mathrm{~Hz})\end{array}$ & $\begin{array}{l}4.63,4.92 \\
(\text { each } 1 \mathrm{H}, \mathrm{d}, J=12 \mathrm{~Hz} \text { ) }\end{array}$ \\
\hline 3 & $6.14(1 \mathrm{H}, \mathrm{brt}, J=6 \mathrm{~Hz})$ & $6.13(1 \mathrm{H}, \mathrm{brdt}, J=6,1 \mathrm{~Hz})$ & $6.28(1 \mathrm{H}, \mathrm{t}, J=6 \mathrm{~Hz})$ & $6.30(1 \mathrm{H}, \mathrm{brt}, J=6 \mathrm{~Hz})$ \\
\hline 4 & $4.44(2 \mathrm{H}, \mathrm{d}, J=6 \mathrm{~Hz})$ & $4.43(2 \mathrm{H}, \mathrm{brd}, J=6 \mathrm{~Hz})$ & $4.55-4.61^{c)}$ & $4.61(2 \mathrm{H}, \mathrm{d}, J=6 \mathrm{~Hz})$ \\
\hline 5 & $1.76(3 \mathrm{H}, \mathrm{s})$ & $1.71(3 \mathrm{H}, \mathrm{s})$ & $4.55-4.61^{c)}$ & $4.62(2 \mathrm{H}, \mathrm{s})$ \\
\hline $1^{\prime}$ & $4.90(1 \mathrm{H}, \mathrm{d}, J=8 \mathrm{~Hz})$ & $5.43(1 \mathrm{H}, \mathrm{d}, J=8 \mathrm{~Hz})$ & $5.39(1 \mathrm{H}, \mathrm{d}, J=8 \mathrm{~Hz})$ & $5.47(1 \mathrm{H}, \mathrm{d}, J=8 \mathrm{~Hz})$ \\
\hline $2^{\prime}$ & $4.12(1 \mathrm{H}, \mathrm{t}, J=8 \mathrm{~Hz})$ & $4.07(1 \mathrm{H}, \mathrm{dd}, J=8,3 \mathrm{~Hz})$ & $4.01(1 \mathrm{H}, \mathrm{dd}, J=8,3 \mathrm{~Hz})$ & $4.23(1 \mathrm{H}, \mathrm{dd}, J=8,3 \mathrm{~Hz})$ \\
\hline $3^{\prime}$ & $4.25^{c)}$ & $5.08(1 \mathrm{H}, \mathrm{t}, J=3 \mathrm{~Hz})$ & $4.69(1 \mathrm{H}, \mathrm{t}, J=3 \mathrm{~Hz})$ & $6.49(1 \mathrm{H}, \mathrm{brt}, J=3 \mathrm{~Hz})$ \\
\hline $4^{\prime}$ & $4.25^{c)}$ & $5.61(1 \mathrm{H}, \mathrm{dd}, J=10,3 \mathrm{~Hz})$ & $4.03(1 \mathrm{H}, \mathrm{dd}, J=10,3 \mathrm{~Hz})$ & $4.47^{c}(1 \mathrm{H}, \mathrm{brs})$ \\
\hline $5^{\prime}$ & $4.09(1 \mathrm{H}, \mathrm{m})$ & $4.74(1 \mathrm{H}, \mathrm{ddd}, J=10,5,2 \mathrm{~Hz})$ & $4.52(1 \mathrm{H}, \mathrm{ddd}, J=10,7,2 \mathrm{~Hz})$ & $4.47^{c)}(1 \mathrm{H}, \mathrm{brs})$ \\
\hline $6^{\prime}$ & $\begin{array}{l}5.02(1 \mathrm{H}, \mathrm{dd}, J=12,5 \mathrm{~Hz}) \\
5.18(1 \mathrm{H}, \mathrm{dd}, J=12,2 \mathrm{~Hz})\end{array}$ & $\begin{array}{l}4.19(1 \mathrm{H}, \mathrm{dd}, J=12,5 \mathrm{~Hz}) \\
4.31(1 \mathrm{H}, \mathrm{dd}, J=12,2 \mathrm{~Hz})\end{array}$ & $\begin{array}{l}4.71(1 \mathrm{H}, \mathrm{dd}, J=12,7 \mathrm{~Hz}) \\
4.95(1 \mathrm{H}, \mathrm{dd}, J=12,2 \mathrm{~Hz})\end{array}$ & $\begin{array}{l}4.36(1 \mathrm{H}, \mathrm{dd}, J=11,3 \mathrm{~Hz}), \\
4.51(1 \mathrm{H}, \mathrm{brd}, J=11 \mathrm{~Hz})\end{array}$ \\
\hline $2^{\prime \prime}$ & $8.23(2 \mathrm{H}, \mathrm{d}, J=8.5 \mathrm{~Hz}), \mathrm{H}-2^{\prime \prime}, 6^{\prime \prime}$ & $7.52(1 \mathrm{H}, \mathrm{d}, J=2 \mathrm{~Hz})$ & $7.35(1 \mathrm{H}, \mathrm{d}, J=2 \mathrm{~Hz})$ & $7.51(1 \mathrm{H}, \mathrm{d}, J=2 \mathrm{~Hz})$ \\
\hline $3^{\prime \prime}$ & $7.12(2 \mathrm{H}, \mathrm{d}, J=8.5 \mathrm{~Hz}), \mathrm{H}-3^{\prime \prime}, 5^{\prime \prime}$ & & & \\
\hline $5^{\prime \prime}$ & & $7.21(1 \mathrm{H}, \mathrm{d}, J=8 \mathrm{~Hz})$ & $7.17(1 \mathrm{H}, \mathrm{d}, J=8 \mathrm{~Hz})$ & $7.18(1 \mathrm{H}, \mathrm{d}, J=8 \mathrm{~Hz})$ \\
\hline $6^{\prime \prime}$ & & $7.06(1 \mathrm{H}, \mathrm{dd}, J=8,2 \mathrm{~Hz})$ & $6.90(1 \mathrm{H}, \mathrm{dd}, J=8,2 \mathrm{~Hz})$ & $7.08(1 \mathrm{H}, \mathrm{dd}, J=8,2 \mathrm{~Hz})$ \\
\hline$\alpha$ & & $6.53(1 \mathrm{H}, \mathrm{d}, J=16 \mathrm{~Hz})$ & $3.72(2 \mathrm{H}, \mathrm{s})$ & $6.70(1 \mathrm{H}, \mathrm{d}, J=16 \mathrm{~Hz})$ \\
\hline$\beta$ & & $7.73(1 \mathrm{H}, \mathrm{d}, J=16 \mathrm{~Hz})$ & & $8.01(1 \mathrm{H}, \mathrm{d}, J=16 \mathrm{~Hz})$ \\
\hline
\end{tabular}

Measured at a) $600 \mathrm{MHz}$ and $b$ ) $400 \mathrm{MHz}$. c) Overlapped signals.

hexanolide (18) had a bitter taste, but have not yet been evaluated quantitatively. The tasted compounds, and 2,5dihydroxyphenylacetic acid (homogentisic acid), have an acrid taste and their distribution in the plant kingdom is known. ${ }^{16,17)}$ It is suggested that the bitter taste is due to the presence of phenylacetic acid derivatives esterified with glucose or allose, at least for the taste compounds isolated in the present investigation. For example, hymenoside L (8) has the bitter taste, although cardiomanol (12) and hymenoside $\mathrm{P}$ (11) don't show any taste; thus, it is clear that a phenylacetyl group is necessary for the bitter taste.

\section{Experimental}

General Experimental Procedures TLC was carried out on silica gel precoated glass plates with $\mathrm{CHCl}_{3}-\mathrm{MeOH}(4: 1$ and $7: 3 \mathrm{v} / \mathrm{v})$ or $\mathrm{CHCl}_{3}-\mathrm{MeOH}-\mathrm{H}_{2} \mathrm{O}(15: 6: 1$ and $65: 35: 5 \mathrm{v} / \mathrm{v})$. Detection was performed with Godin reagent. For normal-phase column chromatography (CC), silica gel $60(40-63 \mu \mathrm{m})$ was used. The mixture of $\mathrm{CH}_{2} \mathrm{Cl}_{2}-\mathrm{MeOH}(1: 1)$ was used for column chromatography on Sephadex LH-20 as a solvent. Optical rotations were recorded on a JASCO DIP-1000 automatic digital polarime- ter. NMR spectra were recorded at 150 and $100 \mathrm{MHz}$ for ${ }^{13} \mathrm{C}$, and at 600 and $400 \mathrm{MHz}$ for ${ }^{1} \mathrm{H}$ on a Varian UNITY 600 and JEOL ECP-400. The chemical shifts are given in $\delta(\mathrm{ppm})$ with tetramethylsilane as an internal standard. UV spectra were recorded in spectroscopic-grade EtOH on a Hitachi U3000. IR spectra were measured on a JASCO FT/IR-41. GC-MS spectra were recorded on a Hewlett-Packard HP-6890 gas chromatograph with a 5972A mass selective detector. The temperature programming for GC-MS analysis was performed from 50 to $250^{\circ} \mathrm{C}$ at $8^{\circ} \mathrm{C} / \mathrm{min}$, and isothermal at $250^{\circ} \mathrm{C}$ for $5 \mathrm{~min}$. The injection temperature was $250^{\circ} \mathrm{C}$. A fused silica column coated with DB-17 $(30 \mathrm{~m} \times 0.25 \mathrm{~mm}$ i.d., film thickness $0.25 \mu \mathrm{m})$ was used. Helium was used as the carrier gas at $1 \mathrm{ml} / \mathrm{min}$.

Extraction and Isolation of Compounds Hymenophyllum barbatum was collected in August 1997 in Kaifu-gun, Tokushima. The air-dried and mechanically ground powder $(2.42 \mathrm{~kg})$ was extracted with methanol for 1 month at room temperature to give a crude extract $(459.2 \mathrm{~g})$.

Part $(70 \mathrm{~g})$ of the $n$-butanol-soluble fraction $(158.0 \mathrm{~g})$ was chromatographed on DIAION HP-20 using a $\mathrm{CH}_{3} \mathrm{OH}-\mathrm{H}_{2} \mathrm{O}$ gradient, giving seven fractions. The third fraction $(7.8 \mathrm{~g})$ was rechromatographed on Sephadex LH-20 to give a mixture of hymenosides $\mathrm{K}, \mathrm{L}$ and $\mathrm{N}-\mathrm{U}$, which were further purified by silica gel column chromatography using $\mathrm{CHCl}_{3}-\mathrm{MeOH}-\mathrm{H}_{2} \mathrm{O}$, followed by middle pressure liquid chromatography (MPLC) to yield 11 hemiterpene glycosides, hymenosides $\mathrm{K}, \mathrm{L}$ and $\mathrm{N}-\mathrm{U}$ 
Table 1. (Continued) ${ }^{1} \mathrm{H}-\mathrm{NMR}$ Data of Hymenosides O (10), P (11), M (15), W (16) and U (17)

\begin{tabular}{|c|c|c|c|c|c|}
\hline No. & $10^{a)}$ & $11^{b)}$ & $15^{c)}$ & $16^{b)}$ & $17^{b)}$ \\
\hline 1 & $\begin{array}{l}4.56-4.64,{ }^{d)} 4.86 \\
(\text { each } 1 \mathrm{H}, \text { br d, } J=12 \mathrm{~Hz})\end{array}$ & $\begin{array}{l}4.58-4.63,{ }^{d)} 4.90 \\
(\text { each } 1 \mathrm{H}, \text { br d, } J=11 \mathrm{~Hz})\end{array}$ & $\begin{array}{l}4.21,4.37 \\
(\text { each } 1 \mathrm{H}, \text { br d, } J=12 \mathrm{~Hz})\end{array}$ & $\begin{array}{l}4.64,4.87 \\
(\text { each } 1 \mathrm{H}, \text { br d, } J=13 \mathrm{~Hz} \text { ) }\end{array}$ & \\
\hline 2 & & & & & $\begin{array}{l}2.76(\mathrm{dd}, J=17,5 \mathrm{~Hz}) \\
3.02(\mathrm{br} \mathrm{dd}, J=17,4 \mathrm{~Hz})\end{array}$ \\
\hline 3 & $6.27(1 \mathrm{H}, \mathrm{brt}, J=6 \mathrm{~Hz})$ & $6.29(1 \mathrm{H}, \mathrm{brt}, J=6 \mathrm{~Hz})$ & $4.27(1 \mathrm{H}, \mathrm{brt}, J=7 \mathrm{~Hz})$ & $4.87^{d)}$ & $4.18-4.29^{d)}$ \\
\hline 4 & $4.56-4.64^{d)}$ & $4.58-4.63^{d)}$ & $\begin{array}{l}3.56(1 \mathrm{H}, \mathrm{dd}, J=12,7 \mathrm{~Hz}), \\
3.64-3.69^{d)}\end{array}$ & $\begin{array}{l}4.08(1 \mathrm{H}, \mathrm{dd}, J=11,7 \mathrm{~Hz}) \\
\left.4.17-4.22^{d}\right)\end{array}$ & $\begin{array}{l}1.54(\mathrm{dd}, J=14,4 \mathrm{~Hz}), \\
1.90(\mathrm{br} \mathrm{d}, J=14 \mathrm{~Hz})\end{array}$ \\
\hline 5 & $4.56-4.64^{d)}$ & $4.58-4.63^{d)}$ & $\begin{array}{l}5.26(1 \mathrm{H}, \mathrm{bs}), \mathrm{Hb} \\
5.27(1 \mathrm{H}, \mathrm{bs}), \mathrm{Ha}\end{array}$ & $\begin{array}{l}5.55(1 \mathrm{H}, \mathrm{br} \mathrm{s}), \mathrm{Ha} \\
5.63(1 \mathrm{H}, \mathrm{br} \mathrm{s}), \mathrm{Hb}\end{array}$ & $4.67(1 \mathrm{H}, \mathrm{m})$ \\
\hline 6 & & & & & $1.20(3 \mathrm{H}, \mathrm{d}, J=6 \mathrm{~Hz})$ \\
\hline $1^{\prime}$ & $5.53(1 \mathrm{H}, \mathrm{d}, J=8 \mathrm{~Hz})$ & $5.45(1 \mathrm{H}, \mathrm{d}, J=8 \mathrm{~Hz})$ & $4.65(1 \mathrm{H}, \mathrm{d}, J=8 \mathrm{~Hz})$ & $4.94(1 \mathrm{H}, \mathrm{d}, J=7.7 \mathrm{~Hz})$ & $4.92(1 \mathrm{H}, \mathrm{d}, J=8 \mathrm{~Hz})$ \\
\hline $2^{\prime}$ & $4.09(1 \mathrm{H}, \mathrm{dd}, J=8,3 \mathrm{~Hz})$ & $4.05(1 \mathrm{H}, \mathrm{dd}, J=8,3 \mathrm{~Hz})$ & $3.33(1 \mathrm{H}, \mathrm{dd}, J=8,3 \mathrm{~Hz})$ & $4.04(1 \mathrm{H}, \mathrm{dd}, J=8,7.7 \mathrm{~Hz})$ & $5.52(1 \mathrm{H}, \mathrm{t}, J=8 \mathrm{~Hz})$ \\
\hline $3^{\prime}$ & $5.07(1 \mathrm{H}$, brt,$J=3 \mathrm{~Hz})$ & $4.75(1 \mathrm{H}, \mathrm{t}, J=3 \mathrm{~Hz})$ & $4.04(1 \mathrm{H}, \mathrm{t}, J=3 \mathrm{~Hz})$ & $4.17-4.22^{d)}$ & $4.18-4.29^{d)}$ \\
\hline $4^{\prime}$ & $5.61(1 \mathrm{H}, \mathrm{dd}, J=10,3 \mathrm{~Hz})$ & $4.14(1 \mathrm{H}, \mathrm{dd}, J=10,3 \mathrm{~Hz})$ & $3.46(1 \mathrm{H}, \mathrm{dd}, J=10,3 \mathrm{~Hz})$ & $4.17-4.22^{d)}$ & $4.18-4.29^{d)}$ \\
\hline $5^{\prime}$ & $(1 \mathrm{H}, \mathrm{ddd}, J=10,5,2 \mathrm{~Hz})$ & $4.58-4.63^{d)}$ & $3.64-3.69^{d)}$ & $3.88(1 \mathrm{H}, \mathrm{m})$ & $3.90(1 \mathrm{H}, \mathrm{m})$ \\
\hline $6^{\prime}$ & $\begin{array}{l}4.17(1 \mathrm{H}, \mathrm{dd}, J=12,5 \mathrm{~Hz}), \\
4.29(1 \mathrm{H}, \mathrm{dd}, J=12,2 \mathrm{~Hz})\end{array}$ & $\begin{array}{l}4.87(1 \mathrm{H}, \mathrm{dd}, J=12,6 \mathrm{~Hz}), \\
5.07(1 \mathrm{H}, \mathrm{dd}, J=12,2 \mathrm{~Hz})\end{array}$ & $\begin{array}{l}3.62(1 \mathrm{H}, \mathrm{dd}, J=11,6 \mathrm{~Hz}), \\
3.84(1 \mathrm{H}, \mathrm{dd}, J=11,2 \mathrm{~Hz})\end{array}$ & $\begin{array}{l}4.31(1 \mathrm{H}, \mathrm{dd}, J=12,5 \mathrm{~Hz}) \\
4.48(1 \mathrm{H}, \mathrm{dd}, J=12,2 \mathrm{~Hz})\end{array}$ & $\begin{array}{l}4.18-4.29,{ }^{d)} 4.48 \\
(1 \mathrm{H}, \mathrm{brd}, J=12 \mathrm{~Hz})\end{array}$ \\
\hline $2^{\prime \prime}$ & $7.51(1 \mathrm{H}, \mathrm{d}, J=2 \mathrm{~Hz})$ & $7.58(1 \mathrm{H}, \mathrm{d}, J=2 \mathrm{~Hz})$ & & & $7.38(1 \mathrm{H}, \mathrm{d}, J=2 \mathrm{~Hz})$ \\
\hline $5^{\prime \prime}$ & $7.20(1 \mathrm{H}, \mathrm{d}, J=8 \mathrm{~Hz})$ & $7.19(1 \mathrm{H}, \mathrm{d}, J=8 \mathrm{~Hz})$ & & & $7.17(1 \mathrm{H}, \mathrm{d}, J=8 \mathrm{~Hz})$ \\
\hline $6^{\prime \prime}$ & $7.07(1 \mathrm{H}, \mathrm{dd}, J=8,2 \mathrm{~Hz})$ & $7.13(1 \mathrm{H}, \mathrm{dd}, J=8,2 \mathrm{~Hz})$ & & & $6.93(1 \mathrm{H}, \mathrm{dd}, J=8,2 \mathrm{~Hz})$ \\
\hline$\alpha$ & $6.53(1 \mathrm{H}, \mathrm{d}, J=16 \mathrm{~Hz})$ & $6.67(1 \mathrm{H}, \mathrm{d}, J=16 \mathrm{~Hz})$ & & & $3.74(2 \mathrm{H}, \mathrm{s})$ \\
\hline$\beta$ & $7.91(1 \mathrm{H}, \mathrm{d}, J=16 \mathrm{~Hz})$ & $7.98(1 \mathrm{H}, \mathrm{d}, J=16 \mathrm{~Hz})$ & & & \\
\hline
\end{tabular}

Measured $a$ ) in pyridine- $d_{5}$ at $\left.600 \mathrm{MHz}, b\right)$ in pyridine- $d_{5}$ at $400 \mathrm{MHz}, c$ ) in methanol- $d_{4}$ at $600 \mathrm{MHz}$. $d$ ) Overlapped signals.

Table 2. ${ }^{13} \mathrm{C}-\mathrm{NMR}$ Data of Hymenosides K (1), Q (3), R (4), S (5), T (6), V (7), L (8), N (9), O (10), P (11), M (15), W (16) and U (17)

\begin{tabular}{|c|c|c|c|c|c|c|c|c|c|c|c|c|c|}
\hline No. & $\mathbf{1}^{a)}$ & $3^{b)}$ & $4^{b)}$ & $\mathbf{5}^{b)}$ & $\mathbf{6}^{b)}$ & $7^{a)}$ & $\mathbf{8}^{a)}$ & $\mathbf{9}^{a)}$ & $10^{a)}$ & $11^{b)}$ & $15^{c)}$ & $16^{c)}$ & $17^{b)}$ \\
\hline 1 & 74.4 & 75.1 & 74.6 & 74.3 & 74.2 & 74.6 & 72.2 & 72.2 & 72.3 & $72.1^{e)}$ & 71.4 & 70.3 & 169.6 \\
\hline 2 & 133.2 & 133.2 & 135.2 & 132.9 & 133.0 & 133.7 & 138.2 & 138.5 & 138.4 & 138.1 & 147.2 & 146.7 & 37.0 \\
\hline 3 & 128.8 & 128.9 & 133.4 & 128.9 & 129.3 & 128.8 & 131.3 & 131.1 & 131.1 & 131.2 & 74.4 & 74.4 & 70.8 \\
\hline 4 & 58.6 & 58.4 & 58.6 & 58.5 & 58.2 & 38.6 & $58.3^{e)}$ & $58.3^{e)}$ & $58.3^{e)}$ & $58.2^{f f}$ & 66.4 & 66.1 & 34.9 \\
\hline 5 & 14.0 & 14.0 & 14.2 & 14.0 & 13.8 & 14.3 & $58.5^{e)}$ & $58.4^{e)}$ & $58.4^{e)}$ & $58.3^{f}$ & 115.1 & 115.7 & 72.1 \\
\hline 6 & & & & & & & & & & & & & 21.1 \\
\hline $1^{\prime}$ & 101.0 & 103.3 & 103.3 & 100.9 & 103.0 & 101.4 & 101.3 & 102.0 & 101.6 & 101.3 & 101.1 & 102.8 & 100.7 \\
\hline $2^{\prime}$ & 75.5 & 74.4 & 75.0 & 75.4 & 74.8 & 72.0 & 72.3 & 70.9 & 72.1 & $72.2^{e)}$ & 72.3 & 75.0 & 74.9 \\
\hline $3^{\prime}$ & 76.1 & 79.5 & 78.3 & 76.1 & 78.1 & 70.4 & $72.87^{f)}$ & 75.3 & 70.4 & $72.8^{g)}$ & 73.0 & $78.1^{e)}$ & 75.6 \\
\hline $4^{\prime}$ & 71.8 & 72.9 & 71.6 & 71.7 & 71.2 & 70.9 & 69.2 & 67.6 & 70.9 & 69.0 & 69.0 & 71.6 & 71.3 \\
\hline $5^{\prime}$ & 78.7 & 78.2 & 75.2 & 78.6 & 75.0 & 73.6 & $72.95^{f)}$ & 76.8 & 73.6 & $73.0^{g)}$ & 75.5 & $78.0^{e)}$ & 78.4 \\
\hline $6^{\prime}$ & 62.5 & 62.0 & 65.0 & 62.4 & 64.4 & 62.1 & 65.6 & 62.7 & 62.1 & 65.0 & 63.2 & 62.7 & 62.1 \\
\hline $1^{\prime \prime}$ & 126.2 & 126.3 & 126.1 & 125.3 & 121.3 & 126.8 & 126.2 & 127.1 & 126.8 & 126.8 & & & 125.8 \\
\hline $2^{\prime \prime}$ & 118.1 & 117.8 & 117.8 & $131.1^{d)}$ & $132.1^{d)}$ & 115.9 & 118.0 & $115.9^{f)}$ & 115.9 & 115.8 & & & 117.4 \\
\hline $3^{\prime \prime}$ & 147.2 & 147.0 & 149.5 & $116.2^{d)}$ & $115.7^{d)}$ & 147.7 & $146.4^{g)}$ & 147.7 & 147.7 & 147.5 & & & 146.9 \\
\hline $4^{\prime \prime}$ & 146.3 & 146.0 & 146.3 & 157.9 & 163.2 & 150.6 & $147.3^{g)}$ & 150.4 & 150.6 & 150.3 & & & 146.0 \\
\hline $5^{\prime \prime}$ & 116.5 & 116.2 & 116.5 & $116.2^{d)}$ & $115.7^{d)}$ & 116.7 & 116.6 & 116.7 & 116.7 & 116.6 & & & 116.1 \\
\hline $6^{\prime \prime}$ & 121.2 & 120.9 & 120.9 & $131.1^{d)}$ & $132.1^{d)}$ & 122.2 & 121.1 & 122.1 & 122.2 & 122.0 & & & 120.5 \\
\hline$\alpha$ & 41.2 & 41.2 & 40.8 & 40.8 & & 114.8 & 40.9 & $116.0^{f)}$ & 114.8 & 114.9 & & & 41.0 \\
\hline$\beta$ & & & & & & 146.3 & & 145.8 & 146.3 & 145.8 & & & \\
\hline CO-C-2' & 171.6 & & & 171.5 & & & & & & & & & 171.0 \\
\hline CO-C-6' & & & 172.3 & & 166.4 & & 172.5 & & & 167.6 & & & \\
\hline$\underline{\mathrm{CO}}-\mathrm{C}-3^{\prime}$ & & 172.2 & & & & & & 167.9 & & & & & \\
\hline$\underline{\mathrm{CO}}-\mathrm{C}-4^{\prime}$ & & & & & & 167.0 & & & 166.9 & & & & \\
\hline
\end{tabular}

Measured $a$ ) in pyridine- $d_{5}$ at $150 \mathrm{MHz}, b$ ) in pyridine- $d_{5}$ at $100 \mathrm{MHz}, c$ ) in methanol- $d_{4}$ at $150 \mathrm{MHz} . d$ ) Overlapped signals. $e-g$ ) Assignment may be interchangeable in the vertical column.

(1, $164 \mathrm{mg} ; \mathbf{8}, 28 \mathrm{mg} ; \mathbf{9}, 88 \mathrm{mg} ; \mathbf{1 0}, 57 \mathrm{mg} ; \mathbf{1 1}, 40.0 \mathrm{mg} ; \mathbf{3}, 33 \mathrm{mg} ; \mathbf{4}, 12 \mathrm{mg}$; $5,11 \mathrm{mg} ; \mathbf{6}, 6 \mathrm{mg} ; \mathbf{1 7}, 6 \mathrm{mg})$. The second fraction $(5.3 \mathrm{~g})$ was repeatedly chromatographed on Sephadex LH-20 to give a mixture of hymenoside M, $\mathrm{W}$ and 19, which was further chromatographed on silica gel using $\mathrm{CHCl}_{3}-\mathrm{MeOH}-\mathrm{H}_{2} \mathrm{O}$, then repeatedly subjected to MPLC to give hymenoside M $(\mathbf{1 5}, 26 \mathrm{mg})$, W $(\mathbf{1 6}, 28 \mathrm{mg})$ and methyl $(3 R, 5 R)-5$-hydroxy-( $\beta$-D-glucopyranosyloxy)-hexanoate $(19,807 \mathrm{mg})$. The fourth fraction $(27 \mathrm{mg})$ was chromatographed on Sephadex LH-20 to give a mixture of hymenoside V, which was further purified by silica gel column chromatography and MPLC to yield hymenoside $\mathrm{V}(7,5 \mathrm{mg})$.
Hymenoside K (1): Oil; positive HR-FAB-MS $m / z$ : $437.1424[\mathrm{M}+\mathrm{Na}]^{+}$ (Calcd for $\mathrm{C}_{19} \mathrm{H}_{26} \mathrm{O}_{10} \mathrm{Na}$ : 437.1424); $[\alpha]_{\mathrm{D}}^{22}-18.5^{\circ}(c=3.84, \mathrm{MeOH})$; IR $(\mathrm{KBr}) \mathrm{cm}^{-1}: 3252,1730,1607,1447,1281$; UV $\lambda_{\max }(\mathrm{EtOH}) \mathrm{nm}(\log \varepsilon)$ : 206 (4.31), 283 (3.47).

Hymenoside Q (3): Oil; positive HR-FAB-MS $m / z$ : $437.1396[\mathrm{M}+\mathrm{Na}]^{+}$ (Calcd for $\mathrm{C}_{19} \mathrm{H}_{26} \mathrm{O}_{10} \mathrm{Na}$ : 437.1424); $[\alpha]_{\mathrm{D}}^{20}-16.7^{\circ}(c=1.6, \mathrm{MeOH})$; IR $(\mathrm{KBr}) \mathrm{cm}^{-1}: 3323,1727,1525,1287,1079,1040$; UV $\lambda_{\max }(\mathrm{EtOH}) \mathrm{nm}$ $(\log \varepsilon): 205$ (4.40), 230 (3.75), 284 (3.48).

Hymenoside R (4): Oil; positive HR-FAB-MS $m / z: 437.1463[\mathrm{M}+\mathrm{Na}]^{+}$ (Calcd for $\mathrm{C}_{19} \mathrm{H}_{26} \mathrm{O}_{10} \mathrm{Na}$ : 437.1424$) ;[\alpha]_{\mathrm{D}}^{20}-18.3^{\circ}(c=1.2, \mathrm{MeOH})$; IR 
(KBr) $\mathrm{cm}^{-1}: 3316,1734,1287,1080$; UV $\lambda_{\max }(\mathrm{EtOH}) \mathrm{nm}(\log \varepsilon): 205$ (4.41), 236 (3.71), 284 (3.56).

Hymenoside S (5): Oil; positive HR-FAB-MS $m / z: 421.1503[\mathrm{M}+\mathrm{Na}]^{+}$ (Calcd for $\left.\mathrm{C}_{19} \mathrm{H}_{26} \mathrm{O}_{9} \mathrm{Na}: 421.1475\right) ;[\alpha]_{\mathrm{D}}^{20}-21.6^{\circ}(c=1.1, \mathrm{MeOH})$; IR $(\mathrm{KBr})$ $\mathrm{cm}^{-1}: 3333,1734,1518,1225,1151,1079,1034 ;$ UV $\lambda_{\max }(\mathrm{EtOH}) \mathrm{nm}$ $(\log \varepsilon): 202$ (4.17), 225 (3.89), 279 (3.38).

Hymenoside T (6): Oil; positive HR-FAB-MS $m / z: 407.1333[\mathrm{M}+\mathrm{Na}]^{+}$ (Calcd for $\mathrm{C}_{18} \mathrm{H}_{24} \mathrm{O}_{9} \mathrm{Na}$ : 407.1318); $[\alpha]_{\mathrm{D}}^{20}-37.3^{\circ}(c=3.1, \mathrm{MeOH})$; IR $(\mathrm{KBr})$ $\mathrm{cm}^{-1}: 3332,1697,1607,1281,1167,1077 ;$ UV $\lambda_{\max }(\mathrm{EtOH}) \mathrm{nm}(\log \varepsilon): 203$ (4.24), 258 (4.09).

Hymenoside V (7): Oil; positive HR-FAB-MS $m / z$ : $449.1406[\mathrm{M}+\mathrm{Na}]^{+}$ (Calcd for $\mathrm{C}_{20} \mathrm{H}_{26} \mathrm{O}_{10} \mathrm{Na}$ : 449.1424); $[\alpha]_{\mathrm{D}}^{20}+20.6^{\circ}(c=2.4, \mathrm{MeOH})$; IR $(\mathrm{KBr}) \mathrm{cm}^{-1}: 3318,1969,1599,1278,1164 ; \mathrm{UV} \lambda_{\max }(\mathrm{EtOH}) \mathrm{nm}(\log \varepsilon):$ 203 (4.32), 220 (4.16), 244 (3.99), 300 (4.09), 328 (4.18).

Hymenoside L (8): Oil; positive HR-FAB-MS $m / z$ : $453.1373[\mathrm{M}+\mathrm{Na}]^{+}$ (Calcd for $\mathrm{C}_{19} \mathrm{H}_{26} \mathrm{O}_{11} \mathrm{Na}$ : 453.1361); $[\alpha]_{\mathrm{D}}^{20}-30.8^{\circ}(c=1.40$, MeOH); IR $(\mathrm{KBr}) \mathrm{cm}^{-1}: 3555,3194,1726,1289,1094,1607$; UV $\lambda_{\max }(\mathrm{EtOH}) \mathrm{nm}$ $(\log \varepsilon): 205$ (4.41), 283 (3.55).

Hymenoside N (9): Oil; positive HR-FAB-MS $m / z$ : 465.1357: $[\mathrm{M}+\mathrm{Na}]^{+}$ (Calcd for $\mathrm{C}_{20} \mathrm{H}_{26} \mathrm{O}_{11} \mathrm{Na}$ : 465.1373); $[\alpha]_{\mathrm{D}}^{22}-34.0^{\circ}(c=4.4$, MeOH); IR $(\mathrm{KBr}) \mathrm{cm}^{-1}: 3385,1703,1603,1269,1157$; UV $\lambda_{\max }(\mathrm{EtOH}) \mathrm{nm}(\log \varepsilon):$ 203 (4.30), 216 (4.09), 244 (3.90), 302 (3.96), 330 (4.09).

Hymenoside O (10): Oil; positive HR-FAB-MS $m / z: 481.1123[\mathrm{M}+\mathrm{K}]^{+}$ (Calcd for $\left.\mathrm{C}_{20} \mathrm{H}_{26} \mathrm{O}_{11} \mathrm{~K}: 481.1112\right) ;[\alpha]_{\mathrm{D}}^{22}-4.7^{\circ}(c=2.8, \mathrm{MeOH})$; IR $(\mathrm{KBr})$ $\mathrm{cm}^{-1}: 3291,1701,1286,1163,1599 ; \mathrm{UV} \lambda_{\max }(\mathrm{EtOH}) \mathrm{nm}(\log \varepsilon): 203$ (4.26), 218 (4.17), 247 (4.02), 300 (4.10), 333 (4.24).

Hymenoside P (11): Amorphous powder; positive HR-FAB-MS $m / z$ : $443.1529[\mathrm{M}+\mathrm{H}]^{+}\left(\right.$Calcd for $\left.\mathrm{C}_{20} \mathrm{H}_{27} \mathrm{O}_{11}: 443.1553\right) ;[\alpha]_{\mathrm{D}}^{20}-50.9^{\circ}(c=1.5$, $\mathrm{MeOH})$; IR (KBr) cm ${ }^{-1}: 3270,1696,1601,1447,1281,1165$; UV $\lambda_{\max }$ $(\mathrm{EtOH}) \mathrm{nm}(\log \varepsilon): 203$ (4.24), 217 (4.14), 245 (3.99), 300 (4.08), 331 (4.22).

Hymenoside M (15): Oil; positive HR-CI-MS $m / z: 281.1217[\mathrm{M}+\mathrm{H}]^{+}$ (Calcd for $\left.\mathrm{C}_{11} \mathrm{H}_{21} \mathrm{O}_{8}: 281.1237\right) ;[\alpha]_{\mathrm{D}}^{22}-34.4^{\circ}(c=0.98, \mathrm{MeOH})$; IR $(\mathrm{KBr})$ $\mathrm{cm}^{-1}: 3314,1092$

Hymenoside W (16): Oil; positive HR-FAB-MS $m / z$ : $303.1040[\mathrm{M}+\mathrm{Na}]^{+}$ (Calcd for $\mathrm{C}_{11} \mathrm{H}_{20} \mathrm{O}_{8} \mathrm{Na}$ : 303.1056); $[\alpha]_{\mathrm{D}}^{22}-37.2^{\circ}(c=1.36, \mathrm{MeOH})$; IR (KBr) cm $\mathrm{cm}^{-1}: 3314,1078$.

Hymenoside U (17): Oil; positive HR-FAB-MS $m / z$ : 465.1387 [M+Na] $]^{+}$ (Calcd for $\mathrm{C}_{20} \mathrm{H}_{26} \mathrm{O}_{11} \mathrm{Na}$ : 465.1373); $[\alpha]_{\mathrm{D}}^{20}-29.0^{\circ}(c=2.8, \mathrm{MeOH})$; IR $(\mathrm{KBr}) \mathrm{cm}^{-1}: 3338,1730,1593,1263,1075$; UV $\lambda_{\max }(\mathrm{EtOH}) \mathrm{nm}(\log \varepsilon)$ : 205 (4.39), 234 (3.65), 284 (3.51).

Methyl-(3R,5R)-5-hydroxy-( $\beta$-D-glucopyranosyloxy)-hexanoate (19): Oil; positive HR-CI-MS $m / z$ : $325.1463[\mathrm{M}+1]^{+}$(Calcd for $\mathrm{C}_{13} \mathrm{H}_{25} \mathrm{O}_{9}: 325.1499$ ); $[\alpha]_{\mathrm{D}}^{24}-27.8^{\circ}(c=1.15, \mathrm{MeOH}) ; \mathrm{IR}(\mathrm{KBr}) \mathrm{cm}^{-1}: 3316,1726,1439 .{ }^{1} \mathrm{H}-\mathrm{NMR}$ $\delta: 2.59(1 \mathrm{H}, \mathrm{dd}, J=15,5 \mathrm{~Hz}, \mathrm{H}-2), 2.81(1 \mathrm{H}, \mathrm{dd}, J=15,7 \mathrm{~Hz}, \mathrm{H}-2), 4.24$ $(1 \mathrm{H}, \mathrm{br}$ q, $J=7 \mathrm{~Hz}, \mathrm{H}-3), 1.62(1 \mathrm{H}, \mathrm{dt}, J=14,5 \mathrm{~Hz}, \mathrm{H}-4), 1.82(1 \mathrm{H}, \mathrm{dt}, J=14$, $8 \mathrm{~Hz}, \mathrm{H}-4), 3.97(1 \mathrm{H}, \mathrm{m}, \mathrm{H}-5), 1.19(3 \mathrm{H}, \mathrm{d}, J=6 \mathrm{~Hz}, \mathrm{H}-6), 3.67$ (s, OMe), $4.38\left(1 \mathrm{H}, \mathrm{d}, J=8 \mathrm{~Hz}, \mathrm{H}-1^{\prime}\right), 3.14\left(1 \mathrm{H}, \mathrm{dd}, J=9,8 \mathrm{~Hz}, \mathrm{H}-2^{\prime}\right), 3.35(1 \mathrm{H}, \mathrm{t}$, $\left.J=9 \mathrm{~Hz}, \mathrm{H}-3^{\prime}\right), 3.25-3.28^{\mathrm{a}}\left(\mathrm{H}-4^{\prime}, 5^{\prime}\right), 3.65\left(1 \mathrm{H}, \mathrm{dd}, J=12,4 \mathrm{~Hz}, \mathrm{H}-6^{\prime}\right), 3.83$ $\left(1 \mathrm{H}, \mathrm{dd}, J=12,2 \mathrm{~Hz}, \mathrm{H}-6^{\prime}\right) .{ }^{13} \mathrm{C}-\mathrm{NMR} \delta: 173.9(\mathrm{C}-1), 42.1(\mathrm{C}-2), 77.6^{\mathrm{b}}(\mathrm{C}-$ 3), 45.0 (C-4), 66.5 (C-5), 23.9 (C-6), $52.2\left(\mathrm{OCH}_{3}\right), 104.5\left(\mathrm{C}-1^{\prime}\right), 75.0(\mathrm{C}-$ $\left.2^{\prime}\right), 77.8^{\mathrm{b}}\left(\mathrm{C}-3^{\prime}\right), 71.6\left(\mathrm{C}-4^{\prime}\right), 78.1^{\mathrm{b}}\left(\mathrm{C}-5^{\prime}\right), 62.8\left(\mathrm{C}-6^{\prime}\right)\left({ }^{\mathrm{a}}\right.$ overlapped signals, ${ }^{\mathrm{b}}$ assignments may be interchangeable).

Basic Hydrolysis of Hymenosides K (1) and N (9) A solution of $1(43.6 \mathrm{mg}, 9 ; 20 \mathrm{mg}))$ in $20 \% \mathrm{KOH}(2 \mathrm{ml})$ was heated under reflux for $2 \mathrm{~h}$. The reaction mixture was neutralized with $1 \mathrm{~N} \mathrm{HCl}$, then evaporated to dryness. The mixture was chromatographed on silica gel using $\mathrm{CHCl}_{3}-\mathrm{MeOH}-\mathrm{H}_{2} \mathrm{O}$ to give a glycoside $2(18.6 \mathrm{mg})$, of which the ${ }^{1} \mathrm{H}-$ and ${ }^{13} \mathrm{C}$-NMR spectral data were identical with those of $(E)$-2-methyl-but-2-enyl $\beta$-D-glucopyranoside. ${ }^{12)}$ The ${ }^{1} \mathrm{H}$ - and ${ }^{13} \mathrm{C}-\mathrm{NMR}$ data of a glycoside (12; $12.1 \mathrm{mg}$ ) from hymenoside $\mathrm{N}(\mathbf{9})$ were identical with those of cardiomanol (12). . $^{213)}$

Acid Hydrolysis of Hymenoside K (1) and 2 A solution of $\mathbf{1}(20 \mathrm{mg})$ in $5 \% \mathrm{H}_{2} \mathrm{SO}_{4}(2 \mathrm{ml})$ was heated under reflux for $3 \mathrm{~h}$, and a mixture was extracted with ethyl acetate. After evaporation, the residue was methylated with trimethylsilyldiazomethane $(2 \mathrm{ml})$ in $\mathrm{MeOH}(1 \mathrm{ml})$ to give methyl 3,4dimethoxyphenylacetate $(12.3 \mathrm{mg})$, the spectral data of which were identical with those of the authentic material.

A solution of $2(9.3 \mathrm{mg})$ in $5 \% \mathrm{H}_{2} \mathrm{SO}_{4}(2 \mathrm{ml})$ was heated under reflux for $3 \mathrm{~h}$, then diluted with water and passed through a short column on an ion exchange resin, DOWEX-1. The eluate was evaporated to dryness in vacuo, and the residue was dissolved in $\mathrm{H}_{2} \mathrm{O}(2 \mathrm{ml})$. Part of the solution was analyzed by HPLC with a chiral detector, JASCO OR-990 [column: ZORBAX SB-C18, i.d. $3.0 \times 250 \mathrm{~mm}$; mobile phase, $\mathrm{CH}_{3} \mathrm{OH}-\mathrm{H}_{2} \mathrm{O}(1: 1 \mathrm{v} / \mathrm{v})$; column oven temperature, $25^{\circ} \mathrm{C}$; flow rate, $0.5 \mathrm{ml} / \mathrm{min}$; compared with (+)- $\beta$-glucose]. (+)-Glucose was detected. $\mathrm{NaBH}_{4}(10 \mathrm{mg})$ was added to the remaining solution and stirred for $3 \mathrm{~h}$ at room temperature. After neutralization by adding acetic acid, the mixture was evaporated to dryness by repeated codistillation with $\mathrm{MeOH}$. The resulting residue was allowed to stand in $\mathrm{Ac}_{2} \mathrm{O}-\mathrm{C}_{5} \mathrm{H}_{5} \mathrm{~N}(1: 1 \mathrm{v} / \mathrm{v}, 2 \mathrm{ml})$ overnight at room temperature. A sample was subjected to GC-MS analysis to give the glucitol acetate. Further identification was performed by coinjection with authentic glucitol acetate.

Acid Hydrolysis of Hymenoside L (8) A solution of $8(12.0 \mathrm{mg})$ in $5 \%$ $\mathrm{H}_{2} \mathrm{SO}_{4}(2 \mathrm{ml})$ was heated under reflux for $3 \mathrm{~h}$, then diluted with water, and extracted with EtOAc. The aqueous portion was passed through a short column on an ion exchange resin, DOWEX-1. The eluate was concentrated in vacuo, and the residue was dissolved in $\mathrm{H}_{2} \mathrm{O}(2 \mathrm{ml})$. Part of the solution was analyzed using the same method as described earlier. (+)-Allose was detected. The remaining solution was treated in the same manner as described earlier. A sample was subjected to GC-MS analysis to give the alditol acetate of allose. The identification was performed by coinjection with an authentic alditol acetate of allose. The EtOAc layer was evaporated to dryness, then methylated with trimethylsilyldiazomethane $(2 \mathrm{ml})$ in $\mathrm{MeOH}(2 \mathrm{ml})$. A sample was subjected to GC-MS analysis to give methyl 3,4-dimethoxyphenylacetate. The identification was performed by coinjection with authentic sample.

Acid Hydrolysis of Hymenosides N-P (9-11) Each solution of $\mathbf{9}$ $11(9,17 \mathrm{mg} ; \mathbf{1 0}, 18.4 \mathrm{mg} ; \mathbf{1 1}, 8.8 \mathrm{mg})$ in $5 \% \mathrm{H}_{2} \mathrm{SO}_{4}(1 \mathrm{ml})$ was heated under reflux for $3 \mathrm{~h}$, then diluted with water, and extracted with ethyl acetate. The extract was pretreated with $\mathrm{N}, \mathrm{O}$-bis(trimethylsilyl)-acetamide (BSA) and then subjected to GC-MS analysis to give the trimethylsilyl ether (TMS) derivative of caffeic acid. The identification was carried out by coinjection analysis with an authentic TMS derivative of caffeic acid.

The aqueous part was passed through a short column on an ion exchange resin, DOWEX-1. The eluate was concentrated in vacuo, and the residue was dissolved in $\mathrm{H}_{2} \mathrm{O}(2 \mathrm{ml})$. Part of the solution was analyzed using the same method as described earlier. (+)-Allose was detected. The remaining solution was treated in the same manner as described above. A sample was subjected to GC-MS analysis to give the alditol acetate of allose. Further identification was performed by coinjection with an authentic alditol acetate of allose.

Acid Hydrolysis of Hymenoside V (7) A solution of (4.9 mg) in 5\% $\mathrm{H}_{2} \mathrm{SO}_{4}(2 \mathrm{ml})$ was heated for $3 \mathrm{~h}$ and then processed in the same manner as described above to give caffeic acid and allose. The identification of allose by GC-MS analysis was performed using the same method as described earlier. Caffeic acid was identified by GC-MS coinjection analysis of its TMS derivative and authentic sample.

Enzymatic Hydrolysis of Hymenoside U (17) A solution of 16 $(5.53 \mathrm{mg})$ in $\mathrm{H}_{2} \mathrm{O}(1 \mathrm{ml})$ was added to a suspended solution of $\beta$-glucosidase (Nacalai Tesque; $\beta$-glucosidase from sweet almond; $20 \mathrm{mg})$ in $\mathrm{H}_{2} \mathrm{O}(1 \mathrm{ml})$ and stirred at $37^{\circ} \mathrm{C}$ overnight. The mixture was evaporated to dryness. The residue was chromatographed on silica gel $\left[\mathrm{CHCl}_{3}-\mathrm{CH}_{3} \mathrm{OH}(9: 1 \mathrm{v} / \mathrm{v})\right]$ to give $(3 R, 5 R)$-3-hydroxy-5-hexanolide $(0.2 \mathrm{mg}){ }^{2}{ }^{2}$

Acid Hydrolysis of Hymenoside W (16) A solution of (13 mg) in 5\% $\mathrm{H}_{2} \mathrm{SO}_{4}(2 \mathrm{ml})$ was heated for $2 \mathrm{~h}$, then the usual work-up afforded an aglycone. The mixture was passed through a short column on an ion exchange resin, DOWEX-1. The eluate was evaporated to dryness and chromatographed on silica gel using $\mathrm{CHCl}_{3}-\mathrm{MeOH}-\mathrm{H}_{2} \mathrm{O}(15: 6: 1 \mathrm{v} / \mathrm{v})$ to give a glucose, which was identified as (+)-glucose by HPLC with a chiral detector. The earlier eluted fraction containing aglycone was subjected to preparative TLC $\left[\mathrm{CHCl}_{3}-\mathrm{MeOH}-\mathrm{H}_{2} \mathrm{O}(15: 6: 1 \mathrm{v} / \mathrm{v})\right]$, and afforded 2-methylenebutane-1,3,4-tri-ol (3.1 mg).

2-Methylene-butane-1,3,4-triol: Oil; CI-MS $m / z: 119[\mathrm{M}+\mathrm{H}]^{+}, 101,83$; $[\alpha]_{\mathrm{D}}^{17}-20.8^{\circ}(c=0.8, \mathrm{MeOH}) ; \mathrm{IR}$ (neat) $\mathrm{cm}^{-1}: 3419,1652,1418 ;{ }^{1} \mathrm{H}-\mathrm{NMR}$ $\left(400 \mathrm{MHz}, \mathrm{Py}-d_{5}\right) \delta: 4.16(1 \mathrm{H}, \mathrm{dd}, J=11,7 \mathrm{~Hz}, \mathrm{H}-4), 4.24(1 \mathrm{H}, \mathrm{dd}, J=11$, $4 \mathrm{~Hz}, \mathrm{H}-4), 4.71(2 \mathrm{H}, \mathrm{s}, \mathrm{H}-1), 4.92(1 \mathrm{H}, \mathrm{dd}, J=7,4 \mathrm{~Hz}, \mathrm{H}-3), 5.64(2 \mathrm{H}, \mathrm{s}, \mathrm{H}-$ 5), 6.42, 6.60, 6.71 (each $1 \mathrm{H}$, br s, OH); ${ }^{13} \mathrm{C}-\mathrm{NMR}\left(100 \mathrm{MHz}, \mathrm{Py}-d_{5}\right) \delta: 63.4$ (C-1), 67.2 (C-4), 74.8 (C-3), 110.1 (C-5), 152.2 (C-2).

Treatment of 18 with Amberlite 120 B A mixture of $18(18.4 \mathrm{mg})$ in $\mathrm{CH}_{3} \mathrm{OH}(3 \mathrm{ml})$ and Amberlite $120 \mathrm{~B}$ was stirred for $1 \mathrm{~h}$ at room temperature. The mixture was filtered, and the solvent evaporated to give a methyl ester $(20 \mathrm{mg})$. The ${ }^{1} \mathrm{H}-\mathrm{NMR}$ spectrum was identical with that of $\mathbf{1 9}$.

Acknowledgements We are grateful to Professor Shigeru Daigobou (Joetsu University of Education, Joetsu, Niigata, Japan) for the identification of the fern species. This work was supported by a Grant-in-Aid for Scientific Research (A) (No. 11309012) from the Ministry of Education, Culture, Sports, Science and Technology. 


\section{References}

1) Oiso Y., Toyota M., Asakawa Y., Chem. Pharm. Bull., 49, 126-128 (2001).

2) Toyota M., Oiso Y., Asakawa Y., Chem. Pharm. Bull., 49, 1567-1572 (2001).

3) Asakawa Y., "Progress in the Chemistry of Organic Natural Products," Vol. 65, ed. by Herz W., Kirby G. W., Moore R. E., Steglich W., Tamm Ch., Springer, Vienna, 1995, pp. 1-562.

4) Oiso Y., Toyota M., Asakawa Y., Chem. Pharm. Bull., 47, 297-298 (1999).

5) Asakawa Y., J. Bryol., 14, 59-70 (1986).

6) Asakawa Y., "Bryophytes: Their Chemistry and Chemical Taxonomy," ed. by Zinsmeister D. H., Mues R., Oxford University Press, Oxford, 1990, pp. 369-410.

7) Asakawa Y., "Bryophyte Development: Physiology and Biochemistry," ed. by Chopra R. N., Bhatla C. S., CRC Press, Boca Raton, 1990, pp. $259-287$.

8) Asakawa Y., "Bioactive Natural Products: Detection, Isolation, and Structural Determination," ed. by Colegate S. M., Molyneux R. J.,
CRC Press, Boca Raton, 1993, pp. 319-347.

9) Yoshida T., Hashimoto T., Takaoka S., Kan Y., Tori M., Asakawa Y., Pezzuto J. M., Pengsupaarp T., Cordel G. A., Tetrahedron, 52, 14487-14500 (1996).

10) Schofield W. B., "Introduction to Bryology," Macmillan, New York, 1985.

11) Asakawa Y., Toyota M., Oiso Y., Braggins J. E., Chem. Pharm. Bull., 49, 1380-1381 (2001).

12) Nicoletti M., Tomassini L., Planta Med., 58, 472 (1992).

13) Redgwell R. J., Beever R. E., Bieleski R. L., Laracy E. P., Carbohydrate Res., 198, 39-48 (1990).

14) Numata A., Takahashi C., Fujiki R., Kitano E., Kitajima A., Takemura T., Chem. Pharm. Bull., 38, 2862-2865 (1990).

15) Tschesche R., Hoppe H.-J., Snatzke G., Wulff G., Fehlhaber H.-W., Chem. Ber., 104, 1420-1428 (1971).

16) Maruyama E., Uehara K., Kajita T., Hasegawa, C., Kaseigaku Kenkyu, 29, 1-5 (1982).

17) Morishita T., Mukogawa Joshi Daigaku Kiyo, Shokumotsu-hen, 27, $39-43$ (1980). 